\title{
Cambodian Migrants in Thailand: Working Conditions and Issues
}

\author{
John Walsh (Corresponding author), D.Phil. \\ Assistant Professor, School of Management, Shinawatra University \\ BBD Building, 197 Viphawadi-Rangsit Road, Bangkok 10400, Thailand \\ Tel: 66-2-650-6031 E-mail: jcwalsh@siu.ac.th \\ Makararavy Ty $\mathrm{PhD}$. \\ Lecturer, School of Management, Shinawatra University \\ BBD Building, 197 Viphawadi-Rangsit Road, Bangkok 10400, Thailand \\ E-mail: ty.makararavy@gmail.com
}

Received: December 19, $2010 \quad$ Accepted: January 28, 2011 doi:10.5539/ass.v7n7p23

\begin{abstract}
The significant differences in standards of living available across the Thai-Cambodian border are influential in encouraging large numbers of Cambodian migrants to travel for work in Thailand on a temporary or permanent basis. Demand for labour is generally in labour-intensive industries with low value added and the low wages provided act to depress overall earnings. This situation contributes to social tensions and means otherwise uncompetitive work is continued which would otherwise be discontinued because of lack of profitability. Using the findings from qualitative, in-depth interviews with 59 Cambodian migrant workers in Thailand, this paper investigates the types of work that Cambodian migrants are undertaking in Thailand and the conditions in which they live, which is partly determined by the type of work they undertake. Living conditions will in turn determine to some extent the ability of workers to modify their future prospects as remittances change their future prospects.
\end{abstract}

Keywords: Cambodia, Thailand, Migrant labour, Living conditions, Demand for labour

\section{Introduction}

Cambodia has passed through a series of ruinous disasters in the course of history. One of the most remarkable events in history is the Khmer Rouge or Pol Pot regime from 1975-79, during which more than two million people are believed to have been killed. After the genocidal regime collapsed, Khmer or Cambodian people accounted for less than two million in total still living in the country and the majority of them were female and men not normally in the labour force. However, according to the national population census in 2008, completed by the National Institute of Statistics (NIS), Cambodia consisted of about 13 million people, of whom $52 \%$ were female (NIS, 2008), which shows the continuing impact of the war and genocide. The Khmer people have had to strive considerably in order to survive. The land is not uniformly beneficial for wet paddy rice agriculture and, in the event of drought or flood or unanticipated expenses such as medical bills, starvation and indigence might follow. The ability of families to improve their lot in the future is seriously constrained by the expense of education: although mandatory state education is free, there are still semi-hidden costs in terms of stationery and school books, lunch and transportation fees and, in addition, the opportunity costs of children studying when they could be working.

For these reasons, Cambodian people migrated internally and externally. Some of them migrated to western countries such as the USA, France and Australia during and after the civil war ended and some just migrated to neighbouring countries in the region to look for work. The most common destination country has been Thailand, because of the similar language and culture and because it is comparatively easy to cross the border either legally or illegally. However, the relationship between Cambodia and Thailand has been problematic, for such reasons as the treatment of refugees from the Khmer Rouge by the Thai army, the perception that Thai institutions have occupied Khmer territory and, mote recently, by inflammatory remarks allegedly made by a Thai actress that led 
to rioting in Phnom Penh and the escalation of tension over ownership of the Preah Vihear temple issue (e.g. McCartan, 2008; Symon, 2008).

In order to have closer control over illegal immigrants, a Memorandum of Understanding (MoU) on Cooperation in Employment of Workers with Thailand was signed in 2003 and the recruitment of Khmer workers under this MoU started in 2006. The MoU is based on the principles in the 1999 Bangkok Declaration on Irregular Migration and requires regular consultation at senior or ministerial level at least once a year. The first article of the MOU lists its four main areas of application: (1) proper employment procedures; (2) collaboration on effective repatriation of workers; (3) due protection of workers; (4) prevention and effective action against illegal border crossing, trafficking and illegal employment. The current regulations permit Khmer workers to work in certain provinces in Thailand and in certain occupations only. Moving beyond the specified and permitted provinces is illegal. The purpose of legal inwards migration into Thailand is for workers to take jobs that Thai workers do not wish to take at the level of wages offered. This includes plantation and fisheries work, both of which are low paid with minimum wage rates are in operation and close to the $3 \mathrm{D}$ definition of dirty, dangerous and demeaning. Illegal migrants are more likely to find employment in the low paid service sector, petty trading or as part of the burgeoning karaoke bar industry.

In contrast with the better known situation of Burmese [Myanmarese] workers, the working conditions facing migrant Cambodians are less well-established. A variety of reasons has contributed to this lack of knowledge, including practical difficulties, language issues, visibility issues of workers and so forth. This study aims to provide some additional baseline information concerning the type of work that Cambodian migrants are doing in Thailand, what problems they face, what are their aspirations and related issues through a program of semi-structured personal interviews.

\section{Literature Review}

Migration has recently became a new topic of interest for the government, international organizations and Non Governmental Organizations (NGOs) working in Cambodia. Previously, most research studies and interventions were concentrated on human trafficking, especially sexual exploitation, and forced migration (resettled of refugees from civil war, displacements etc.). Research (ILO, 2006) in Cambodia and Thailand indicates that there are several key challenges for safe migrant recruitment in Cambodia: the formal recruitment process is considered to be ponderous and expensive and so informal channels remain popular; workers do not always find the work they expected or that was advertised to them and have little power over when employment ends; formal recruitment does not, furthermore, necessarily offer better opportunities or conditions and the system is not properly policed or regulated. As Martin observed (2003:50), "Thailand will likely be employing unskilled migrants for years to come, which suggests that the Government should acknowledge a structural dependence on migrants, and establish the institutional framework necessary to develop medium- and long-term migrant policies." To date, this institutional framework has only been constructed to a limited extent and planning has suffered because of a lack of vision and technical capacity and, also, because of the legal weakness of the labour movement, which hinders the tripartite system of negotiation. The current system of registering migrant workers so that they can achieve and maintain legal status has only been partially successful, since it is considered expensive and reduces the power of some employers to take maximum advantage from the labour they employ. Some 850,000 workers were registered under the scheme, from an estimated total of two million migrant workers in 2010 (McCartan, 2010).

Some understanding of the conditions facing Khmer workers has been gleaned from Acharya (2003) and the ILO (2006). These works also approach issues involved with working in the informal sector. The treatment that Cambodian deportees from Thailand receive during the migration process has been explored by Olivie (2008), who found inappropriate use of law, evidence of abuse and lack of necessary skills and knowledge among the various police and regulatory authorities involved. Thailand has not to date signed the 1951 Convention on Refugees nor the Protocol of 1967 and so there is little differentiation of treatment between illegal migrant workers, trafficked persons and refugees. The situation facing Burmese workers is a little better known. It is not, of course, a pleasant tale (e.g. Amnesty International, 2005). Literature covering labour migration as a whole is of course increasingly well-established. Bodies of work are being developed to cover the transnational phenomena and the lessons are disseminated by such bodies as the International Organization of Migration (IOM), while specific instances of migration flows to or from specific locations is also becoming better-documented. When, therefore, it comes to addressing less well-known instances of labour migration such as are explored in this paper, it is possible to relate existing frameworks of analysis to observations made in the field in a way that enriches the findings here. In particular, the paper expands on knowledge of Cambodian migrants in the realms of working and living conditions, as well as the sociology of living in a society that is 
occasionally hostile to them. The qualitative aspects of this phenomenon are easy to understand and integrate into the existing body of knowledge than the quantitative aspects, since there is very little agreement among authorities of the scope of migration from Cambodia and estimates vary enormously.

\section{Methodology}

Data was collected using both primary and secondary data collection methods. The primary data interviewing was conducted in March 2010, using a face to face method with semi-structured questionnaires. Since the migrant workers were present in different sectors across the country, the interviews took place in six provinces of Thailand (the Hat Lek border crossing region, Chanthaburi, Khon Kaen, Sa Keo, Pathum Thani and Ayudhya), where large numbers of Cambodian migrants either worked or transited. Most Cambodian migrants seem to enter into Thailand via five main ports of entry: the Hat Lek border with Koh Kong province, Ban Laem, Cham Sa Ngam border with Banteay Mean Chey province, Chong Jom of Pailin municipality and Aranyaprathet. Each in-depth interview took about 1-2 hours including workplace observations (atmosphere, working environment, employee and employer relationships). In total, 59 interviews were conducted. The interviews were conducted in Khmer and the interviewer used extensive note taking of the responses of interviewees and these notes were subsequently transcribed and interpreted into English for analysis and redaction. The method selected for choosing respondents was based on convenience and some snowballing references from interviewees. It cannot be claimed that the sample of respondents is properly representative of all migrant workers or representative of any particular location or activity. However, it is hoped that the sample achieved provides a reasonable approximation of the experiences of Khmer workers as a whole. The interviews are supplemented by secondary data and, indeed, ethnographic observations of the people concerned.

\section{Research Findings}

Most of the migrants surveyed were male ( $83 \%)$ and only $17 \%$ female $(n=59$ in all cases). Only $10 \%$ were married and $90 \%$ had received education to no more than Grade 4, which means they left school when they were about 10 years old. The majority of respondents averaged some 35 years old. All of them professed to be Buddhists. Among the interviewees, nine worked in the fishery sector, 41 in food selling and nine in construction. In other words, the majority of the workers are part of the unskilled labour market and very few had any skill or training that would enable them to command above minimum wage rates or to have much power over their working conditions.

Although there were some variations, it is clear that the majority of migrants interviewed came from poor, agricultural background families which had insufficient ability to feed and support all family members. This was typically because of the small size of land that was available and its lack of fertility, presumably because of the continued prevalence of traditional techniques and the lack of capital and innovation necessary for improving productivity or producing more value-added items. Natural disasters such as drought and flooding also exacerbated the problems. The need to earn income and the comparative ease and familiarity of travelling to Thailand make this an obvious strategy for workers to take. In some cases, respondents observed that, had they not taken this option, they would have felt ashamed or would have been criticized by their family members. It is not a coincidence, in this case, that $90 \%$ of respondents were single, in that it is people in such circumstances who are able to take the decision to migrate. As many as 45 respondents admitted that they had crossed the border illegally, either through their own efforts or with the aid of intermediaries. Some respondents had crossed the border many times and had learned how to manage the system according to their own circumstances. Acharya (2003) mentioned that the improvement of transportation networks facilitates the physical movement of migrants within and outsides the country. Clearly, in this context, the development of the border post at Poipet has made it more possible for people to travel. It has also been argued (e.g. Massey et al., 1993; Harris and Todaro, 1970) that the decision to migrate is not based exclusively on the perception of economic advantages, as represented by the wage differentials between sending and receiving areas but, also, on the perception of an improvement in the quality of life, not only related to economic factors. It was notable that the majority of respondents measured the differential in their own cases as up to $500 \%$ of more of what they could have earned at home; further, despite the problems that they faced in terms of discrimination, loneliness, harassment and so forth, most still reported that their lifestyle as a migrant worker was actually better than it would have been if they had not travelled.

The study found that Khmer migrants faced various challenges at the workplace. In terms of payment, it is difficult to calculate the wage according to minimum wage set by the Royal Thai Government (RTG) because many workers work on piece rates (the minimum wage varies from province to province based on the cost of living but is usually around 170-190 baht per day, which is approximately US\$5-6). The wages varied from 
4,000 to 7,000 baht per month according to the type of work done. As previously observed, this level is much higher than would be available in rural Cambodia. Respondents observed that they would have been earning around 1,000 baht (or US\$30) if they had not migrated. However, there were common problems with being paid. Some respondents had salaries several months in arrears and others had their pay docked for 'mistakes' such as damaging stock or equipment or being late for work. If they wanted to have a day off or were obliged to be absent for some reason, then their wages would also be reduced on a pro-rata basis. All the respondents noted that they did not receive regular days off in any month and, further, they often faced the problem of being required to work excess unpaid hours. In other words, the migrant workers were not being protected by Thai Labour Protection Act, which limits the standard work day at eight hours with statutory breaks.

The status of the workers was also diminished by the fact that so many respondents had entered the country illegally or else they were not in possession of proper documentation. Of the 59 respondents, only 14 had legal status and they were travelling to Thailand on a seasonal basis when they could take time off from their rice-growing duties. The need to be present for rice-growing in Cambodia revolves around a 4-6 month period during the rainy season. Apart from this, workers are free to find work elsewhere. However, it was notable that the respondents felt that they would not be able to find work in Phnom Penh, despite the number of construction projects taking place there. Perhaps it is more possible for women to find work in and around the city, while the men must travel overseas.

The illegal status of many workers meant that they could not seek any legal protection from abusive employers or anyone else. Very few respondents (less than $10 \%$ ) had any kind of formal employment contract and neither did they have health insurance or social security. If they needed to seek medical treatment, they understood that they would have to pay for it themselves and would also miss wages for time away from work. Most respondents would, if necessary, purchase medicine from a nearby pharmacy where a wide range of medicines are available without prescription. One respondent observed that she needed help from another Cambodian worker to take care of her while she was unwell and practiced the traditional method of 'Kosh Kjol.' She could not approach a doctor at an official hospital because her illegal status put her at risk of being arrested and deported.

According to around $80 \%$ of the respondents, the workers faced discrimination in the workplace. They generally felt discriminated against by contrast with both Burmese and Laotian migrants; the former were said to have the benefit of numbers, of being better skilled and of having an association which helped them with practical matters, while the latter had the benefit of speaking a language very similar to Thai. Although Khmer and Thai have some similarities, most people grow up not learning any of the language of their neighbours and tend to have very little knowledge of events or people across the border. Many respondents observed that it was difficult for them to work properly until they were able to speak at least enough Thai as to be to communicate to a reasonable extent. By contrast, Khmer migrants felt that Thai employers preferred Laotian and Burmese migrant workers because their ability in Thai language was generally higher. They also felt, generally, that workers from the other two countries were in Thailand because of political problems rather than as economic migrants, which was the situation for the Khmer workers. It was stated that discrimination means that Cambodian workers were paid around 20\% less than Burmese and Laotian migrants. They were also less likely to suffer from isolation and psychological problems brought about from not being able to communicate with other people. Some respondents reported that, for fear of discrimination from other people including customers, they hid their nationality and would not speak to other Cambodians in public and not in the Khmer language at all. One respondent who worked in a market reported not speaking to other Cambodians who were working in the same area, for fear of revealing their identity. Discrimination might occasionally manifest itself in terms of physical abuse. Some male employees reported being subjected to verbal and physical abuse; one woman respondent reported that when she was delivered via intermediary to her future employer, she was unable to resist his sexual advances and subsequently accepted money for the process.

In terms of dealing with their income, the most common pattern (of about $80 \%$ of the sample) was for the remittance of some $50 \%$ of their salary back to their families and retaining the remainder for personal use. A Khmer intermediary or a known and trusted person who crossed the border frequently would be used to carry the money physically (for which a fee was normally charged). In the great majority of cases (around 90\%), respondents observed that their family conditions had materially improved since they had begun their remittances: children were able to go to school, debts had been repaid, shelters could be repaired or new ones built and so forth. The remainder of respondents observed that their family's material condition had not improved since they had been in Thailand and, in some cases, the situation had become worse. There is, of course, always the danger that respondents have, systematically, been scrupulous with the truth for their own reasons. It is hoped that using a Khmer interviewer with skills in personal interviewing will have reduced this 
risk. Reducing the risk is not, of course, the same as eliminating it. It might also be noted that the respondents were, almost universally, negative towards the Cambodian Embassy staff and officials, suggesting a willingness to be candid.

When asked about their dealings with the Cambodian Embassy in Thailand, the respondents were generally dissatisfied. They observed that when they had called for interventions by Embassy staff the responses had mostly been very poor. In some cases, when respondents wanted to report a serious problem, they found that they could not contact the relevant official or that the official declined to help. Indeed, this was the reason given by some respondents as to why they chose not to hold a passport, register with the authorities as a legal worker and deal with the paperwork because it was all very costly, time-consuming and inconvenient when it came to obtaining contact with the required Embassy officials. Although the official fee for applying for a passport is US\$30, in fact the fee varies in practice between US\$120-150, depending on the amount of time spent waiting. Respondents observed that if only the official fee was attached to the application papers, then it might take years for it to be processed. This type of corruption is one of the principal motivating factors for people choosing to cross the border illegally. Further, when workers are registered officially, then they are not allowed to travel to another other than the specified province or area in which they are permitted to work. They are obliged to obtain permission from the police before travelling, they must report to the police every 90 days, to inform the authorities when they change their workplace and also to pay for the processing of documents. Of course, on each such occasion, there is an opportunity for harassment or requests for additional fees. The potential for problems exists on both sides of the border: those respondents who had been deported reported that they found themselves liable to pay on both sides and also face detention for some period. There were no signs of sexual abuse during this process in the current sample, although that might be different if more women had been interviewed.

As might have been anticipated, employers often preferred to hire illegal rather than legal workers for a variety of reasons. One of the main reasons is of course that illegal workers can be hired at lower costs. Pressure on the illegal worker to avoid the authorities makes for a lower direct wage rate and also means much lower indirect rates of wages in terms of health insurance, social security, paperwork for the work permit process and the opportunity costs attached with the time required to deal with all of these issues. On the other hand, there were some migrants (especially those with skills) who wished to register as legal workers so as to obtain protection from Thai authorities and other civil society organizations. Some respondents had requested their employers to process the legal documents but they were still waiting for progress without any positive response at the time of interviewing.

A substantial proportion of the respondents had been coming to Thailand for five or more years. In a small number of cases, the respondents had experience of Thailand since their childhood - for example, one person had a father who had been active in the Khmer Rouge and who had been travelling in the border areas for many years and had many contacts. It was, however, much more common for respondents to find their own way in Thai society and to accumulate knowledge individually over the course of time. This includes learning the best way for them to navigate the passport and border crossing and related issues. Many respondents stressed the lack of solidarity with their colleagues in Thailand and it would appear that there is a need for the development of a mechanism by which this knowledge (insofar as it is possible to deal in knowledge of how to circumvent the laws) may be collected and distributed as required. Of course, regularization of regulations and the policing of those regulations would be beneficial for all concerned but there are many other issues which would need to be resolved before that could be achieved.

As far as setting a target for returning home is concerned, some respondents had specific plans but few seem to have set specific goals. In other words, while some respondents felt that they would remain in Thailand or travel to and fro for a certain number of years but not for any particular purpose other than having done their duty. Some research of Indonesian migrants in Malaysia indicates that, presumably through communication among the people involved, a certain proportion of migrants have identified specific goals (e.g. buying a plot of land and building a homestead on it) which would require a predictable period of time, perhaps five or seven years, to complete (Balakrishnan et al., 2009). There is little evidence of this form of thinking in the current study.

\section{Conclusion and Discussion}

There is little doubt that there will be forces encouraging outward migration of workers from Cambodia and forces encouraging inward migration of workers into Thailand for the foreseeable future. The demand for labour in Cambodia in terms of decent work is insufficient for the size of the population and many of the new industrial projects involve Chinese investment and the use of Chinese workers. The economy of the country continues to 
rely largely on subsistence agriculture and there is very little innovation, improvements to productivity or in market institutions that would encourage the growing of more added value goods. Deteriorating land-labour ratios have caused the problems to intensify and, increasingly, farming families cannot feed themselves. In this situation, the best option that appears to people is to migrate to Thailand for work. Owing to their limited skills and education, they have little choice but to become involved in sectors requiring basic labour only, such as selling food, domestic service, fishing, plantation and agricultural work. The migrants might not necessarily be able to earn higher wage rates by migrating, although many do, but their total income is likely to have increased because work in Thailand is available for most of the year. However, the economic status of many migrants does improve when higher wages are obtained or when long-term experience, crossing and re-crossing the border, enables workers to move into higher paying occupations. Even so, there are a number of negative effects associated with working in Thailand. These include the legal issues mentioned, the discrimination and the cultural differences.

At the same time, there is a need for the relative agencies of the Thai government to plan for how migrant workers are to be used in the future and what their role in the economy overall should be. Currently, the use of large numbers of semi-legal or illegal migrant workers is acting to suppress wage rates generally, causing further inward migration of Thai workers since, as otherwise unprofitable economic activities are made profitable because of low labour wages, the workers have to move to other provinces to find jobs they wish to take. The Thai economy has, since 2001, been moving away from the East Asian Economic Model (EAEM) as a response to the 1997 and 2008 economic crises and the rise of China and, to a lesser extent, Vietnam. The EAEM was based on export-oriented import-substituting low labour cost-competitiveness factory manufacturing. This is no longer so suitable for the country because, for example, the increased competition from Vietnam and China, rising labour costs in Thailand, the increasingly evident need for further regional development to reduce reliance on the outside world and the impact of external environmental shocks. What, then, should be the role of low-skilled migrant workers in moving the economy onto a different basis? This is perhaps an issue that requires discussion elsewhere.

In terms of practical recommendations, there is a need for improvements in areas such as labour protection, guidelines and procedures for recruitment and migration and the provision of an adequate and effective complaints mechanism.

From an ideological rather than a pragmatic perspective, can it be argued that this sector of migrant labour actually represents a genuine means of escape from poverty for the people involved themselves rather than any others? The argument is between those who, like de Soto (2000), Yunus, the World Bank and many international NGOs who argue that providing poor people with asset security and structured lending programs, for example, will help people escape from poverty through gradually improving their income earning ability in the long-term in a sustainable manner. This is opposed by those such as the sociologist Mike Davis (2007) and, indeed, others following the Marxist tradition, which argues that poverty of this nature is structural and systemic in nature and can only be ended by a radical change in political systems. The evidence in this case is unclear: the majority of respondents believed that their families' economic situation was better because of what they had achieved in terms of remittances but, in support of these claims, only suggested that normal household activities, e.g. education and household maintenance, were facilitated rather than any transformative experience from one class or category to another or, else, the ability to open a new business. Of course, the lack of knowledge about how to begin entrepreneurial activities may be instrumental here.

The testimony of one respondent is illustrative here: "My family has one hectare of rice field, but the field is always inundated during the rainy season. We can cultivate a single crop during the year. The yield becomes lower from year to year, and is now about 0.8 ton per hectare. This is not enough for a big family of about 12 people. Of course, we can just be about self-sufficient for food consumption, but we cannot sell it for earning money. The other sisters and brothers do not have good jobs to earn income for the family, while some of them are still in school. If I do not come to earn money in Thailand, my family will even fall into debt at the local bank or other service because we need to spend to buy agricultural materials and pay for our children to go to school. Before coming, here we borrowed about US\$550 from the local bank. One plot of rice was repossessed by the bank because we could not make the repayment in time. However, since I can earn money here, I can regularly send home my money. So that is the reason of coming to Thailand; it is economic embarrassment."

This recapitulates the experiences of many respondents: their income opportunities, hard-earned as they are, exist to prevent their families sliding into a worse position than they currently are. Indigence is a consistent and recurrent theme and has been observed for decades (Osborne, 2004: 130). This situation has not changed in most parts of the Mekong region. While it remains in force, there will always be a pool of almost desperate individuals 
willing not just to accept any working condition but also to consider it to be better than the situation in which they currently exist.

The proposed establishment of the ASEAN Economic Community in 2015, if it progresses as it is scheduled to do, will enable much greater freedom of movement for workers in the region. Freer movement will presumably see many more Cambodian workers wishing to take advantage of working opportunities in Thailand and will see a decrease in rent-seeking opportunities for labour contractors, customs officials and the police, all of which were reported by respondents in this research study. There may, in a slightly longer timeframe, be more development of Cambodia's industry and, hence, demand for labour within the country. Depending on how this is structured, it may be that more Cambodian workers remain in the country or it may be that, as is currently the case in Thailand, some workers continue to work overseas while, domestically, internal migration increases to meet mismatches in supply and demand for labour.

\section{References}

Acharya, S. (2003). Migration patterns in Cambodia - Causes and consequences. Paper presented at the Ad Hoc Expert Group Meeting on Migration and Development, Bangkok.

Amnesty International. (2005). Thailand: The plight of Burmese migrant workers. [Online] Available: http://www.amnesty.org/en/library/asset/ASA39/001/2005/en/6c36f007-d4e2-11dd-8a23-d58a49c0d652/asa390 012005en.html.

Balakrishnan, Balambigai, Tey Nai Peng, Shyamala Nagaraj and Sabitha Marican. (2009). The intention of migrant workers to stay in Malaysia: A case study of semi-skilled Indonesian migrant workers in Malaysia," paper presented at the ICONSEA (Kuala Lumpur, 2009).

Davis, Mike. (2007). Planet of slums. London and New York: Verso Books.

de Soto, Hernando. (2000). The mystery of capital. London: Basic Books.

Harris, J. R. \& Todaro, M. P. (1970). Migration, unemployment and development: A two-sector analysis. American Economic Review, $L X$.

International Labour Organization (ILO). (2006). The Mekong Challenge: Underpaid, Overworked and Overlooked. Bangkok: ILO.

Martin, Philip. (2003). Thailand: Improving the management of foreign workers. ILO: Bangkok.

Massey D., Arango, J., Hugo, G., Kouaouci, A., Pellegrino, A. \& Taylor, J. E. (1993). Theories of international migration: A review and appraisal. Population and Development Review, 19 (2). 431-66.

McCartan, Brian. (2008). Thailand and Cambodia open fire. Asia Times Online (October 16 ${ }^{\text {th }}$ ). [Online] Available: http://www.atimes.com/atimes/Southeast_Asia/JJ16Ae02.html.

McCartan, Brian. (2010). Migrant warning for Malaysia, Thailand. Asia Times Online (April $1^{\text {st }}$ ). [Online] Available: http://www.atimes.com/atimes/Southeast_Asia/LD01Ae02.html.

National Institute of Statistics (NIS). (2008). The 2008 General Population Census of Cambodia. [Online] Available: http://www.nis.gov.kh/index.php/statistics/surveys/census2008/provisional-population-totals.

Olivie, André. (2008). Identifying Cambodian victims of human trafficking among deportees from Thailand. Phnom Penh: United Nations Inter-Agency Project on Human Trafficking.

Osborne, Milton. (2004). Before Kampuchea: Preludes to tragedy. Bangkok: Orchid Press ( $2^{\text {nd }}$ ed.).

Symon, Andrew. (2008). Temple spat may delay oil riches. Asia Times Online (July $30^{\text {th }}$ ). [Online] Available: http://www.atimes.com/atimes/Southeast_Asia/JG30Ae01.html. 